Journal of Southeast Asian

\title{
[Special Issue on SEA Demographics] Editor's Introduction
}

Wayne E. Wright

University of Texas, San Antonio, wewright@purdue.edu

Follow this and additional works at: https://docs.lib.purdue.edu/jsaaea

Part of the Asian American Studies Commons

\section{Recommended Citation}

Wright, Wayne E. (2008) "[Special Issue on SEA Demographics] Editor's Introduction," Journal of Southeast Asian American Education and Advancement: Vol. 3 : Iss. 1, Article 7.

DOI: $10.7771 / 2153-8999.1103$

Available at: https://docs.lib.purdue.edu/jsaaea/vol3/iss1/7

This document has been made available through Purdue e-Pubs, a service of the Purdue University Libraries. Please contact epubs@purdue.edu for additional information.

This is an Open Access journal. This means that it uses a funding model that does not charge readers or their institutions for access. Readers may freely read, download, copy, distribute, print, search, or link to the full texts of articles. This journal is covered under the CC BY-NC-ND license. 


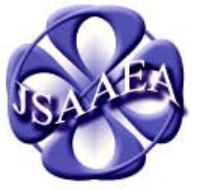

Volume 3

\section{Journal of Southeast Asian American \\ Education \& Advancement \\ WwW.JSAAEA.org}

A peer-reviewed

scholarly journal

published by the

National Association

for the Education \&

Advancement of

Cambodian, Laotian, and Vietnamese Americans (NAFEA)

\title{
Editor's Introduction: Special Issue on Southeast Asian American Demographics
}

\author{
Wayne E. Wright \\ University of Texas, San Antonio
}

I have always been grateful for the work of Dr. Mark E. Pfeifer in making some Southeast Asian American demographic data from the U.S. Census Bureau available through the Hmong Studies Internet Resource Center (www.hmongstudies.com). Anyone who has attempted to retrieve these types of data directly from the American Factfinder internet gateway offered by the Census Bureau (http://factfinder.census.gov) has likely found it difficult to find the exact data of interest, despite its fairly simple user interface. I envisioned this special issue of Journal of Southeast Asian American Education and Advancement (JSAAEA) while working on an article on Southeast Asian Americans (Wright \& Wu, in-press) for the Encyclopedia of Bilingual Education (Gonzalez, in-press). After pulling together and trying to make sense of relevant demographic data, the need for a special issue focused on this topic became apparent.

After discussing the idea with the Associate Editors, we decided to invite Dr. Pfeifer to write an article synthesizing the latest demographic data available from the U.S. Census Bureau's American Community Survey (ACS) for four Southeast Asian American groups coming from the refugee experience-Cambodian, Hmong, Laotian, and Vietnamese. Unlike the Census which is only conducted every ten years, the ACS is a fairly recent effort to collected detailed data each year based on just a sample of the population (see de Klerk and Wiley in this special issue for a detailed explanation and comparison of the U.S. Census and the ACS).

Dr. Pfeifer graciously accepted our invitation and skillfully compiled a substantial amount of useful data into an easily accessible format. At our request, Dr. Pfeifer focused on simply reporting and describing the data, and kept his interpretation to a minimum. His featured article provides a concise summary for the four groups across a wide range of categories: population, age distribution, divorce rate, language, educational attainment, household and family size, disability status, citizenship status, time of arrival, income, homeownership rate, and occupation. Pfeifer's reporting of the data with lightest of analyses makes it easy to see similarities and differences across these four Southeast Asian American groups, and to observe some of the changes over time.

To provide the interpretation of the data, we turned to the expertise of JSAAEA's Editorial Review Board members who represent a wide range of academic fields. Of interest to us was how native and non-native Southeast Asian American scholars from different academic fields would approach and make sense of these data. After preparing a list of possible contributors of brief response articles representing a variety of academic fields, we began to

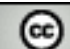

SOMERIGHISRESERVEDReaders are free to copy, display, and distribute this article, as long as the work is attributed to the author(s) and the Journal of Southeast Asian American Education \& Advancement, it is distributed for noncommercial purposes only, and no alteration or transformation is made in the work. More details of this Creative Commons license are available at http://creativecommons.org/licenses/by-nc-nd/3.0/. All other uses must be approved by the author(s) or JSAAEA. 
extend the invitations. Ultimately nine scholars accepted our invitation, read Dr. Pfeifer's featured article, reflected on the data, and wrote response articles. These scholars represent the fields of Asian American Studies (Dr. Peter Nien-chu Kiang), Sociology (Dr. Carl Bankston; doctoral student Yang Sao Xiong), Education (doctoral candidate Phistamay Sychitkokhong Uy), Community Development (Dr. Linda Trinh Vo), Public Policy/Political Science (Dr. Sophal Ear), Counseling/Psychology (Dr. Loan T. Phan) and Language Policy (doctoral candidate Gerda de Klerk and Dr. Terrence G. Wiley). The response authors range from up-and-coming doctoral students to seasoned tenured professors. Over half of the authors are native Southeast Asian Americans, and all have had many years of experience working within SEA communities.

We left the format and style for the response articles fairly open. We provided the following questions as a guide to each author:

- What do these statistics mean to you from the perspective of your field?

- How can some of these data be explained by your academic field?

- What do these data mean in terms of (a) progress since initial refugee resettlement, and (b) remaining or new challenges for the future?

- Are there any data you question or find puzzling based on your own research/experience?

- What are the limitations of the data? What gaps exist in our knowledge of Southeast Asian Americans?

- Any other thoughts or reflections based on these data?

All praised the work of Pfeifer and commented on the usefulness of these data for their respective fields. Each author expressed excitement about measures which illustrate substantial progress since the period of initial refugee resettlement just over 30 years ago. But each also selected specific statistics to highlight and discuss pressing issues that still need to be addressed.

Each author also commented on the limitations of the data. Most expressed concern about how the data as reported in this form can be misleading, providing specific examples from their own research and experience to help explain some of the apparent anomalies in the data. For example, Xiong, Vo, and Phan all describe ways in which the social structure of SEA families paints a different in terms of family income, as multiple family members may be contributing, in contrast to mainstream American homes. Uy observes that larger family sizes also means household income is supporting bigger families than the American average. Bankston and Ear both describe how the large proportion of SEAs in California may skew income data given the higher salaries and cost of living in that state compared to other parts of the country.

The authors highlight the need for data which is further disaggregated than what is reported in Pfeifer's afticle in order to better understand generational and geographic differences within and across groups. Kiang and Bankston, for example, both note problems with how groups are defined, particularly in light of the numbers of foreign-born Amerasians and the growing number of SEAs of mixed race. Disaggregated data may reveal stark differences between these and other SEAs within and across the larger groups. Vo highlights the need disaggregated data to understand academic achievement and income differences between males and females of the 1.5 and second generation.

The authors also discuss what is not in these data. In doing so, they highlight areas of critical need for different kinds of research to further our understanding. Uy, for example, describes the need for more detailed data on SEA K-12 students' academic achievement and drop-out rates. Vo and Kiang note the lack of data on political activity within SEA communities. 
Phan would like to see data on the number of SEA university faculty. Several note how quantitative data from the ACS are unable to help us understand complex social realities within these SEA communities. Kiang mentions the need to understand the role of native language media, religious affiliations, the influence of hip-hop cultural reference points within urban settings, and issues of race and inequality in relation to public health, education, and criminal justice. Bankston notes the need to understand the differences between adaptation and assimilation, and the role of social ethnic networks in understanding differences across and within each group. Ear notes the need to understand differences in socio-economic status within and across groups prior to resettlement, in order to make sense of the differences found in the ACS data. Xiong describes the need to understand how education and language policies are impacting SEA English language learners. Uy is concerned with understanding the larger, overall hardships faced by SEA communities that are masked by the ACS data. Kiang problematizes the meanings of "progress" as constructed in the limited ACS data, and provides alternatives for viewing progress.

Kiang, Xiong, and Uy commented specifically on the limitations of the language data reported in Pfeifer's article, and expressed concern about the misleading picture the data in this format create. Uy also lamented the lack of data related to literacy. In light of these comments, the contribution from de Klerk and Wiley is of particular value. These authors echo the concerns raised by the others, and provide their own critique of the limited value of the ACS data and the misleading ways these data are reported out, particularly when relying solely on reports generated by the user-interface of the American Factfinder. Going beyond this simple interface, de Klerk and Wiley utilize raw data available for download from this same website in order to demonstrate the potential for much more sophisticated analyses. Using the Vietnamese group as an example, they show how these data can be disaggregated, grouped, cross-tabulated, and used to create surrogate measures in order to provide a more deeper and accurate picture of issues related to language and literacy within the group. These same techniques could easily be applied to other categories within the ACS data.

Xiong and Vo commented on the incompleteness of these data as they only focus on four SEA groups. Unrepresented in these data are other Southeast Asians of the refugee experience such as the Khmu, I-Dang, Iu Mieng, and the Tai Dam, just to mention a few. In Pfeifer's defense, he was specifically asked to focus only on the four largest groups. Our concern is that the sampling procedures of the ACS result in substantial margins of error. This means that numbers reported may be off by tens of thousands of people. As several authors have rightly questioned the accuracy of the reported data for the larger groups, it is unclear how accurate or misleading the data would be for these smaller groups, had they been included. One earlier reviewer of Pfeifer's article was deeply concerned about this lack of representation of the other groups. We were reminded us that these numbers represent real people, real lives, and real communities, and that the results of such demographic studies can impact individuals at a deep emotional level. Also absent from these data are Southeast Asian Americans who are not a part of the original refugee experience, such as the growing number of Thai Americans, and new refugees from Burma/Myanmar. JSAAEA will certainly welcome any article in the future focusing on one or more of these Southeast Asian American groups not represented in this special issue. For example, some of the responders observed that unrepresented in these data are the recent Hmong refugees from Wat Tham Krabok. The next special issue of JSAAEA will focus specifically on this group. 
Speculating on the meaning of the data for the future, Bankston notes that Southeast Asian Americans will make up a large percentage of the American population, and describes a "normalization" of SEA groups with other ethnic groups in the United States. Xiong wonders what impact the rising education level with SEA groups will have on the future. Ear speculates on the impact of the growing affluence of the communities, commenting that with affluence comes change. Kiang observes that the third generation of SEAs is now entering elementary school, and thus will force us to re-think our current dichotomies of "refugees" and "newcomers." Vo suggests that within the next 20 years, SEAs will face the same struggles native-born Japanese Americans face today in sustaining ethnic communities.

Full discussion of these issues and many more lie in the pages that follow. We wish to express our sincere gratitude to Dr. Mark Pfeifer and each of the nine scholars who helped us to understand the meanings and limitations of these important data from their respective fields and personal insights. Together they provide us with a deeper understanding of what we know and what we don't know. Their critiques provide a framework for additional quantitative, qualitative, and mixed-methods research studies that need to be conducted to further our knowledge and understanding of the education and advancement of Southeast Asian Americans and their communities.

\section{References}

Gonzalez, J. M. (Ed.). Encyclopedia of Bilingual Education. Thousand Oaks, CA: Sage Publications, Inc.

Wright, W. E., \& Wu, H.-p. (in-press). Southeast Asian American refugees to the U.S. In J. M. Gonzalez (Ed.), Encyclopedia of Bilingual Education. Thousand Oaks, CA: Sage Publications, Inc. 


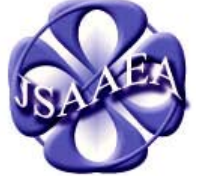

Volume 3

\section{Journal of Southeast Asian American Education \& Advancement} WwW.JSAAEA.org
A peer-reviewed scholarly journal published by the National Association for the Education \& Advancement of Cambodian, Laotian, and Vietnamese Americans (NAFEA)

\section{Editor}

Dr. Wayne E. Wright

University of Texas, San Antonio

Associate Editors

Dr. Chhany Sak-Humphry

University of Hawaii

Dr. KimOanh Nguyen-Lam

California State University, Long Beach

Book Review Editor

Dr. Leslie Turpin

School for International Training

Creative Works Editor

Phouang Hamilton

Washington Office of Superintendent of Public Instruction

Special Advisor

Anne Frank

University of California, Irvine, Southeast Asian Archives

Editorial Assistant

Mariana Kuhl

University of Texas, San Antonio

Comments and questions for the editorial staff may be directed to jsaaea@lists.sis.utsa.edu

\section{Editorial Review Board}

\author{
Dr. Carl L. Bankston III \\ Tulane University \\ Dr. Phala Chea \\ Lowell Public Schools \\ Dr. Changming Duan \\ University of Missouri, Kansas City \\ Dr. Nancy H. Hornberger \\ University of Pennsylvania \\ Dr. Peter Nien-Chu Kiang \\ University of Massachusetts, Boston \\ Dr. Stacey Lee \\ University of Wisconsin, Madison
}

\author{
Dr. Pollie Bith-Melander \\ Asian and Pacific Islander Wellness Center \\ Dr. George Chigas \\ University of Massachusetts, Lowell \\ Dr. Sophal Ear \\ U.S. Naval Postgraduate School \\ Dr. Samlong Inthaly \\ Minneapolis Public Schools \\ Dr. Kevin K. Kumashiro \\ University of Illinois, Chicago \\ Dr. David Chanpannha Ley \\ Montgomery County Public Schools
}


Dr. Sue Needham

California State University, Dominguez Hills

Dr. Max Niedzwiecki

Rights Working Group

Dr. Clara Park

California State University, Northridge

Dr. Loan T. Phan

University of New Hampshire

Dr. Karen Quintiliani

California State University, Long Beach

Dr. Fay Shin

California State University, Long Beach

Dr. Yer J. Thao

Portland State University

Dr. Khatharya Um

University of California, Berkeley

Dr. Terrence G. Wiley

Arizona State University

\section{Dr. Bic Ngo}

University of Wisconsin-Madison

Dr. Leakhena Nou

California State University, Long Beach

Dr. Mark Pfeifer

Texas A\&M University, Corpus Christi

Dr. Bounlieng Phommasouvanh

Minnesota Department of Education

Dr. Kalyani Rai

University of Wisconsin, Milwaukee

Dr. Nancy J. Smith-Hefner

Boston University

Dr. Myluong Tran

San Diego State University

Dr. Linda Trinh Vo

University of California, Irvine

Dr. Zha Blong Xiong

University of Minnesota

Dr. Kou Yang

California State University, Stanislaus

\section{Doctoral Student Editorial Review Board}

\author{
Keo Chea \\ University of Pennsylvania \\ Loan Dao \\ University of California, Berkeley \\ Ha Lam \\ Arizona State University \\ Vanna Som \\ Harvard University \\ Giang Pham \\ University of Minnesota \\ Tinou Tran \\ University of Houston, Texas \\ Phitsamay Sychitkokhong Uy \\ Harvard University
}

Vichet Chhuon

University of California, Santa Barbara

Annie BichLoan Duong

San Joaquin County Office of Education

Ravy Lao

University of California, Santa Barbara

Rassamichanh Souryasack

University of California, Santa Barbara

Layheng Ting

State University of New York, Albany

Loan Tran

University of California, Santa Barbara

Yang Sao Xiong

University of California, Los Angeles 